\title{
INCIDENCE AND DISTRIPTION OF IN MITES (ACARI) ASSOCIATED WITH DATE PALM TREES IN ISMAILIA GOVERNORATE, EGYPT
}

\author{
EL-KADY, G.A. ${ }^{1}$; T.A. SALMAN², M.K. ABBAS ${ }^{2}$ and H.M. EL- SHARABASY1
}

1. Plant Protection Dept., Faculty of Agriculture, Suez Canal University, Ismailia, Egypt.

2. Plant Protection Research Institute. ARC, Dokki, Giza. Egypt

(Manuscript received 30 August 2016)

\begin{abstract}
$\mathrm{T}$ he aim of this work was to survey mites on varieties of date palm trees at Ismailia Governorate. Results reveled that, the occurrence of 13 mite species belonging to 8 families. These mites were classified according to their feeding habits into three categories; four mite species belonging to two families are phytophagous; eight mite species belonging to five families are predaceous and one mite species is miscellaneous feeding. Results show also that, mite extracted from Hayani variety were more dominant than Zaghloul variety. Raoiella indica Hirst was the highest number as phytophagous mites. On the other hand, Amblyseius swirskii (A.-H.) recorded the highest population as predaceous mites. Cheletogenes orntus (Can.\&Fons.) and Saniosulus nudus summers also found in high numbers in Hayani variety as predaceous mites. Results show that, from 4191 mites were counted in the first year of study; phytophagous were $39.2 \%$ \& $40.3 \%$; predaceous mites were $57.1 \%$ \& $56.2 \%$ and the miscellaneous mite species were $3.7 \%$ \& $3.7 \%$ from Hayani and Zaghloul varieties, respectively. In the second year of study; from 5791 mite individuals were counted; phytophagous were $41.7 \%$ \& $39.2 \%$; as well as the predaceous mites recorded $55.4 \% \& 56.5 \%$ and the miscellaneous mite species were $2.9 \% \& 4.4 \%$ from Hayani and Zaghloul varieties, respectively.
\end{abstract}

Key words: Mites, Date palm trees, Incidence.

\section{INTRODUCTION}

Date palm trees (Phoejnix dactylifera L.) are one of the important ecosystem for number of living organisms specially mites and insect. Date palm trees are cultivated and distributed all over Egypt. It is one of the major and earliest fruit crops. It is provide a primary article of food and commerce in the great desert and semidesert areas extending from western North Africa to India. Also it is a commercial crop in many other subtropical desert areas. Survey of mites associated with palm trees was studied by many author; El-Kady (1997); El-Halawany et al., (2001), Sallam and Attia (2005); El-Sanady and Mohamed (2013); Radwan and Attia (2013). El- Kady (1997) surveyed mites associated with date palm trees at 12 locations in North and South Sinai Peninsula, with occurrence eighteen species belonging to twelve families 
that classified to six species of two families were phytophagous and eight species of six families were predaceous. El Halawany et al., (2001) studied mites inhabiting date palms in Egypt for two years. They found, 16 mite species belonging to 11 families. Sallam and Yassin (2005), surveyed mites associated with date palm trees at ElWahat, El- Baharia Oasis. El Sanady and Mohamed (2013) studied the biodiversity and seasonal abundance of mites associated with two varieties of date palms in Giza and Sohag Governorates, Egypt. They found 37 mite species representing 31 genera, 17 families. Mesbah, (2014), surveyed mites associated with date palm trees in Giza and Sharkia Governorates during two successive years.

The present work aims of to study the incidence and dominance of mites associated with two varieties of date palm trees in Ismailia Governorate and discuss the role of predaceous mites as biological control agents.

\section{MATERIALS AND METHODS}

Two varieties of date palm trees (Hayani and Zaghloul) were choosen in this study at different districts in Ismailia Governorate. Samples of six compacted leaves (about $50 \mathrm{~cm}$ for each) were collected monthly for each variety. Incidence of mites was done during two successive years; from March 2012 to February 2014. Samples of compacted leaves were placed in plastic bags and transferred to the laboratory. Mites were isolated by using Tullgren funnels for 24 hours and mounted in Hoyer's medium. Identification of specimens to species according to Krantz, 1978 and Zaher, 1986. Mite dominance was classified into three categories $+=$ Rare $(<20$ individuals $($ leave) $++=20-40$ Moderate (individuals(leave) and $+++>40 \mathrm{High}$ (individuals leave).

\section{RESULTS AND DISCUSSION}

Results presented in Table (1) show the identification and dominoes of mites inhabiting two varieties of date palm trees in Ismailia Governorate. The obtained results, of the collected mites from leaves of date palm were belonging to thirteen mite species belonging to eight families. Based on the generally known of the primary feeding habits, mites were categorized into three trophic groups, Phytophagous, predaceous and miscellaneous. The phytophagous mites were numerically dominant of four mite species belonging to two families. Whereas eight mite species are predaceous mites belonging to five families. Moreover, the miscellaneous presented. Tyrophogous putrescentiae of family Acoridae, Acaridida. 
These results are agreement with El- Kady (1997) who survey of mites associated with date palm trees at 12 locations in North and South Sinai Peninsula. Results revealed the occurrence of 18 mite species belonging to 12 families. Of these six mite species of two families are phytophagous; eight mite species of six mite families are predaceous.

El Halawany et al (2001) found, 16 mite species of mites belonging to 11 families were collected. Sallam \& Yassin (2005), recorded mites associated with date palm at El-Wahat El- Baharia Oasis; the study proved presence of 36 mite species belonging to 33 genera in 18 families. Mesbah, (2014), surveyed mites associated with date palm trees in Giza and Sharkia governorates during two successive years (2012- 2013). Results revealed that, 26 mite species belonging to 17 families.

Results show that the dominant mite species extracted from Hayani variety more than that of Zaghloul variety (Table1). Results shown that, Raoiella indica (Family Tenipalpidae) was recorded highest number as phytophagous mites. On the other hand, Amblyseius swirskii (Family: Phytoseiidae) recorded the highest number as Predaceous mites: where by Cheletogenes orntus (Family: Cheyletidae) and Saniosulus nudus (Family: Eupalopsellidae) found in high number in Hayani variety as Predaceous mites.

This results are agree with that obtained by El-Kady (1997) ; El- Sanady \& Mohamed (2013); El- Halawany et al., (2010) who recorded that Oligonychus. afrassiaticus; Ambbyseius swrskii; Cheletogenes orntus and S. nudus were dominant species infested date palm trees. 
Table 1. Incidence and dominance of mites species associated with two varieties of date palm trees at Ismailia governorate during the course of study from (March 2012 to Feb.2014).

\begin{tabular}{|c|c|c|c|}
\hline \multirow{2}{*}{ Feeding habit of mites } & \multirow[b]{2}{*}{ Family - species } & \multicolumn{2}{|c|}{ Varieties } \\
\hline & & Hayani & Zaghloul \\
\hline \multirow{2}{*}{ I: Phytophagous } & $\begin{array}{c}\text { Tetranychidae Donnadieu } \\
\text {-Oligonychus afrassiaticus McGregor } \\
\text {-Eutetranychus orientalis (Klein) }\end{array}$ & $\begin{array}{l}++ \\
++\end{array}$ & $\begin{array}{l}++ \\
++\end{array}$ \\
\hline & $\begin{array}{c}\text { Tenuipalpidae Berlese } \\
\text {-Raoiella indicae Hirst } \\
\text {-Phyllotetranychus aegypticus Sayed }\end{array}$ & $\begin{array}{l}+++ \\
++ \\
\end{array}$ & $\begin{array}{l}++ \\
+ \\
\end{array}$ \\
\hline \multirow{5}{*}{ II:Predaceous } & $\begin{array}{c}\text { Phytoseiidae Berlese } \\
\text {-Amblyseius swirskii (A.-H.) } \\
\text {-Amblyseius cydnodactylon Shehata\& Zaher }\end{array}$ & $\begin{array}{c}+++ \\
+ \\
\end{array}$ & $\begin{array}{r}+++ \\
+ \\
\end{array}$ \\
\hline & $\begin{array}{l}\text { Stigmaeidae Oudemans } \\
\text { - } \quad \text { Agistemus exsertus Gonzalez } \\
\text { _ } \quad \text { Agistemus africanus Soliman\&Gomaa }\end{array}$ & $\begin{array}{l}++ \\
+ \\
\end{array}$ & $\begin{array}{l}+ \\
+ \\
\end{array}$ \\
\hline & $\begin{array}{c}\text { Cheyletidae } \\
\text {-Cheletogenes ornatus (Can.\&Fons.) } \\
\text { - Cheyletus fortis Oud. }\end{array}$ & $\begin{array}{c}+++ \\
+ \\
+\end{array}$ & $\begin{array}{l}++ \\
+ \\
\end{array}$ \\
\hline & $\begin{array}{l}\text { Eupalopsellidae Willmann } \\
\text { - } \quad \text { Saniosulus nudus Summers }\end{array}$ & +++ & + \\
\hline & $\begin{array}{l}\text { Raphignathidae } \\
\text { - } \quad \text { Raphignathus ehari }\end{array}$ & ++ & + \\
\hline $\begin{array}{l}\text { III: miscellaneous } \\
\text { feeding }\end{array}$ & $\begin{array}{c}\text { Acaridae Leach } \\
\text {-Tyrophagous putrescentiae (Shrank) }\end{array}$ & + & + \\
\hline
\end{tabular}

$+=$ Rare $(<20$ individuals $\backslash$ leaf $) \quad++=20-40$ Moderate (individuals $\backslash$ leaf) $+++>40$ High(individuals $\backslash$ leaf)

Results show that, from 4191 mite individuals were bound in the first year of study; phytophagous mites were 942 (39.2\%) mites from Hayani variety; 718 (40.3\%) mites from Zaghloul variety. While the Predaceous mites were 1376 (57.1\%) and 1002 (56.2\%) from Hayani and Zaghloul varieties respectively and as well as 89 $(3.7 \%) \& 64(3.7 \%)$ of miscellaneous mites individuals from Hayani and Zaghloul varieties respectively. In the second year from 5791 mites were isolated; 
phytophagous were 1266 (41.7\%) mites individuals from Hayani variety; and 1077 (39.2 \%) mites individuals from Zaghloul variety. Predaceous mites were 1687 (55.4 $\%)$ and 1552 (56.5\%) from Hayani and Zaghloul varieties respectively and 87 (2.9\%) \& $122(4.4 \%)$ miscellaneous mites from Hayani and Zaghloul varieties respectively (Table 2).

Table 2. Total numbers and percentages of mites inhabiting two varieties of date palm trees in Ismailia governorate from March 2012 to February 2014

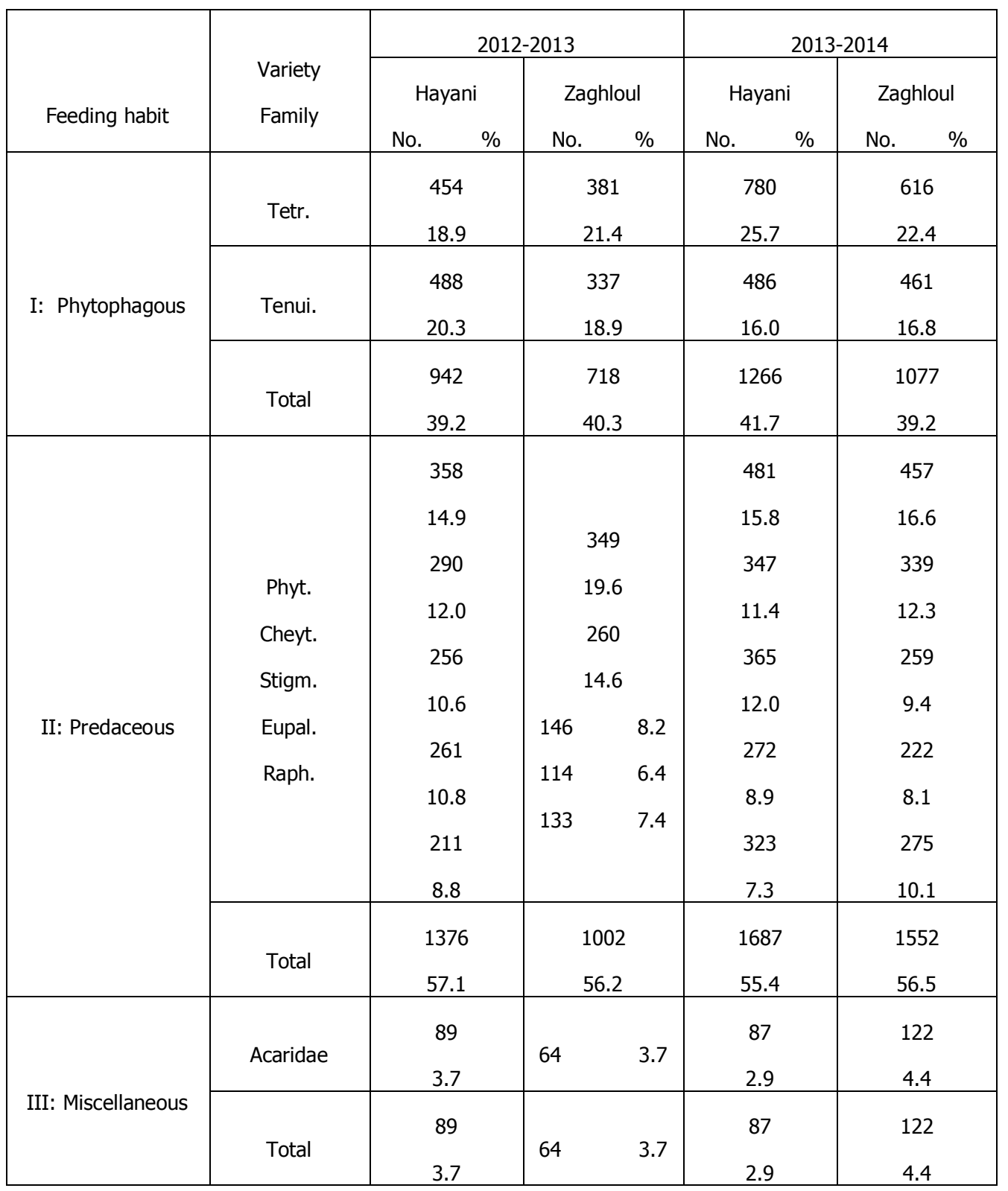




\section{REFERENCES}

1. El-Kady, G.A. 1997. Mites associated with date palm trees in North and South Sinai Peninsula. $7^{\text {th }}$ Nat. Conf. of Pest. \& Dis. of Vegetables \& Fruits in Egypt.

2. El-Halawany, M.E.; Abdel-Samed, M.A. and El-Naggar, M.E. 2001. Mites inhabiting date palms. In Second Inter. Conf. on Date Palm (Al-Ain, UAE, March 25-27, 366-373.

3. El-Sanady, M.A. and Mohamed, A.A. 2013. Biodiversity and seasonal abundance of mites associated with two varieties of date palm in Giza and Sohag governorates, Egypt. Acarines, 7(2): 57-62.

4. Krantz, G.W. 1979. A manual of Acarology. Oregon State Univ. Book- Stores Inc, Corvallis, $509 \mathrm{pp}$.

5. Mesbah, A.E. 2014. Mites inhabiting date palm trees and their dynamics with reference to reproduction and life table parameters of Raoiella indica Hirst (Tenuipalidae) at three different temperatures. Acarines 8 (1): 29-38.

6. Radwan,S.G. and Attia, A.R. 2013. Field study on the two mites species; Hemisarcoptes coophagus Meyer (Astigmata: Hemisarcoptidea) and Phyllotetranychus aegyptiacus Sayd (Prostigmata: Tenuipalpidae) on two varieties of date palm trees at Giza governorate. Acarines 7 (2):29-35.

7. Sally, F.M. Allam and El-Bishlawi, M.O. 2010. Description of immature stage of Aegyptus rhynchphorus (El-Bishlawy \& Allam), (Uropodina, Trachyropodidae). Acarines 4: 3-5.

8. Zaher, M.A. 1984. Survey and ecological studies on phytophagous, predaceous and soil mites in Egypt. III Mites of Sinai Report on PL 480 program U.S.A. Project no EG-ARS 30 Grant No. FG- EG. 


\section{تواجد انتشار الأكاروسات المرتبطة بأشجار نخيل البلح

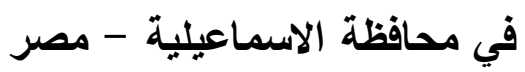

جمال عبد الستار القاضي' ، طارق أحمد عبده سالمان' ، محمد كمال عبد اللطيف عباس ، ،

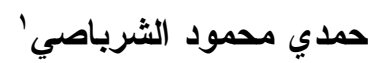

$$
\text { r ا . قسم وقاية النبات - كلبة الزراعة- جامعة قناة السوبس - الاسماعبلية - مصر. }
$$

أجريت هذه الدراسة لتسجيل الأكاروسات المصاحبة لصنفين من أثجار النخيل في محافظة الاسماعيلية ، حيث أظهرت النتائج نو اجد ثلاثة عشر نوعاً من الأكاروسات و التي تنتمي الى ثمانية

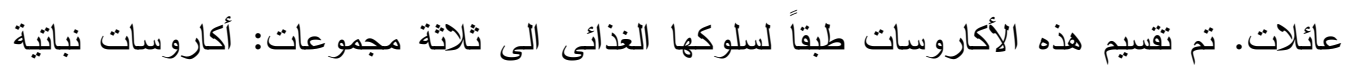

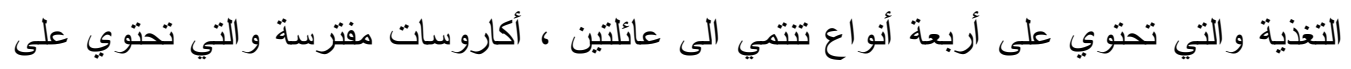

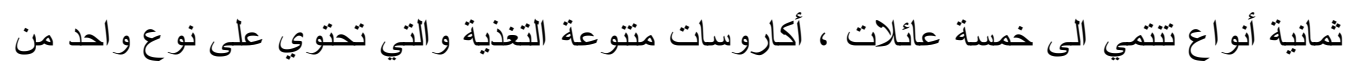

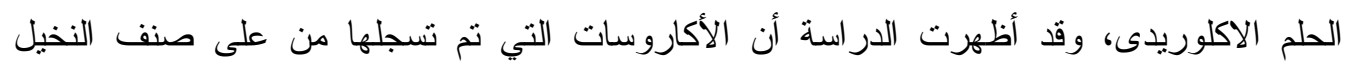

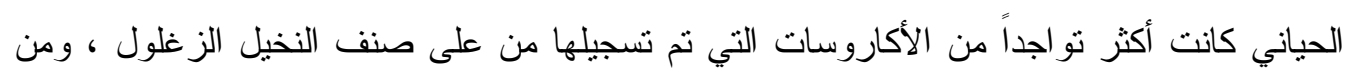

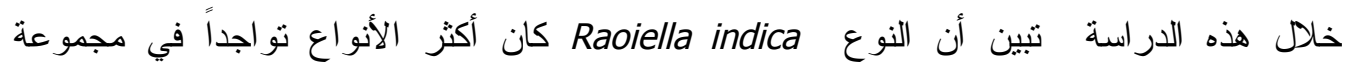

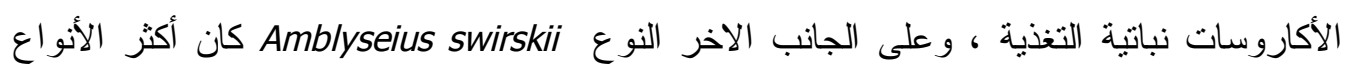

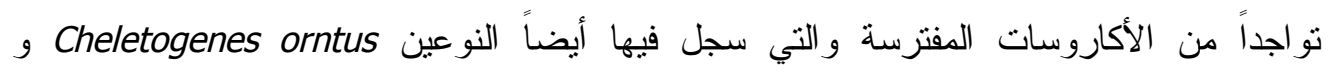
Saniosulus nudus

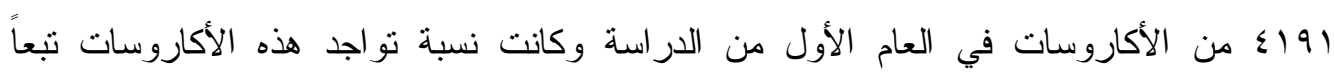
لسلوكها الغذائى كما يلي: الأكاروسات نباتية التغذية سجلت نسبة 30.29 و

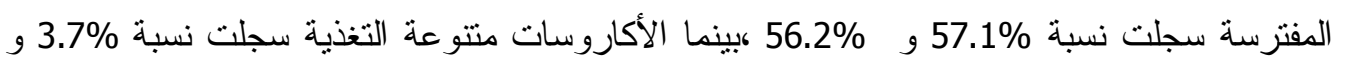
3.7\% وذلك من إجمالي الأكاروسات التي تم فصلها من صنفيى النخيل الحياني و الز غلول بالترتيب ،

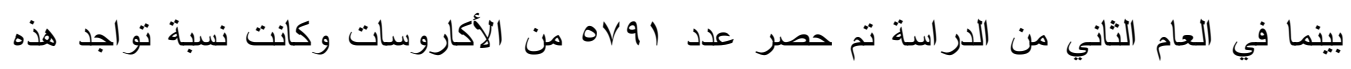

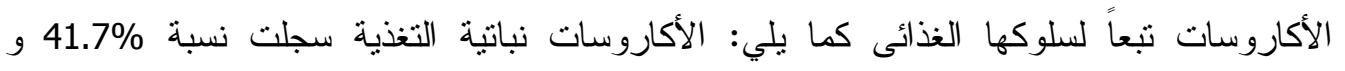

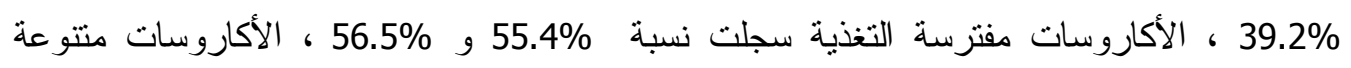
التغذية سجلت نسبة 2.9\% و 4.4\% وذلك من إجمالي الأكاروسات الني نم فصلها من صنفيى النخيل الحياني و الز غلول بالتزتيب . 